\title{
Power and Politics
}

\author{
Thomas Hauer \\ University of Zilina
}

\begin{abstract}
The goal of each policy should be to maintain the country's stability. This proposition becomes a keynote of the political concept of the state. Machiavelli's work The Prince is not just a treatise on politics, but a text aiming to subvert the traditional concept of political philosophy. Machiavelli devoted two main theses to political art. The first one emphasizes that the ruler must work on the assumption that people are bad. Man is inherently evil. Whoever gives the republic its constitution and the law must consider all people evil in advance, and they must also reckon with the fact that the people will show their perverse nature whenever they get the chance. Only this assumption allows the ruler to handle his subjects appropriately; consequently, they are willing to support their leader and his policy. The second thesis claims that the ruler prowess lies in virtue, which is a prerequisite for the ruler's political career. Machiavelli's work is a great contribution to the theory of politics, elites, and power. The text analyses some concepts of this political theory.
\end{abstract}

Keywords: political philosophy, power, techniques of power, virtue, human ambivalence

\section{Introduction}

The most famous Machiavelli’s work The Prince, dedicated to Lorenzo de' Medici was probably supposed to help its author to gain sovereign's favour; although it did not happen, the work went down in history and the ideas contained in it became a basis for future political science (Machiavelli 1855, 26). In general, The Prince can be characterized as a work written very simply and clearly, concisely and, and the same time, it is very rich in content. Machiavelli was able to articulate his thoughts and views on the ideal ruler, or prince (as the Italian title should correctly be translated) — which obviously says something about the time when and for whom Machiavelli wrote The Prince. Although the work undoubtedly reflects the time and purpose (i.e., the desire to please), it contains a very true and realistic view of politics and international relations. Machiavelli's views are often presented as limited to mere "end justifies the means," but in the context of the book, we can understand this slogan somewhat differently than how it is commonly interpreted (M. Unger 2011, 59). An example might be Machiavelli's approach to the sovereign and keeping promises. Machiavelli writes that in an ideal world, every sovereign should obviously keep his word, but because it commonly does not happen, a clever sovereign should know and recognize when it is more advantageous for him and his state to abandon his promise. As a criterion of good governance, Machiavelli also emphasizes benefits not only for the sovereign, but obviously for his entire state-in some places he also states under what circumstances people legitimately overthrow a bad sovereign; in no case does he support a univocal sovereign's authority, as it is sometimes stated.

Thomas Hauer, Ph.D., Prof., Department of Philosophy and Religious Studies, Faculty of Humanities, University of Zilina, Slovakia; main research field: Postmodern Philosophy, Contemporary Philosophy, Philosophy of Technology, Ethics, and Philosophy of the 20th Century. 
Machiavelli's entire work, The Prince included, is characterized by the fact that all ideas are illustrated on examples from the past, as well as Machiavelli's present. In The Prince, Machiavelli is concerned with the governance in the principality, which obviously also reflects the fact that he was trying to please Lorenzo de' Medici at that time. Machiavelli distinguishes between two basic types of principalities, i.e., the hereditary and newly acquired. He gets over with the hereditary principality by observing that it is very easy to govern, because respect for the prince and his family is rooted in the people. He focuses more attention to the new/newly acquired principality. It is because its ruler has a more difficult task since he faces the hope of the people that they will better themselves (which is difficult to achieve); moreover, due to the reorganization of power, he always hurts someone—so it is very hard to please everybody and keep the power.

Furthermore, Machiavelli deals with possibilities of obtaining the throne and distinguishes four basic ways:

(a) Good luck - it may mean that the new ruler came to power very easily, but it will be harder for him to retain power. For one thing, he is not accustomed to deal with difficult situations, and for another, he has minimal confidence of the people;

(b) Merit-according to Machiavelli, the best way to gain the throne is to obtain it by merit. The path to power is indeed laborious, but a lot of problems are already solved on the way to the throne, so the new ruler does not have such difficulty maintaining authority and order;

(c) Crime-he considers obtaining power through a crime wrong for the very reason that the subjects would probably not acknowledge the sovereign and would do everything to get rid of him;

(d) The will of the co-citizens is the last way to come to power. In this context, Machiavelli primarily warns against capriciousness of public opinion-therefore, the new ruler must beware of any unpopular steps that could change this opinion.

Machiavelli proceeds from a large amount of experience that he gained during his diplomatic trips. Not being able to be directly present in the politics of Florence, he wanted to make use of his knowledge and to help not only the then ruler, but especially his beloved country. That is why he wrote The Prince. Machiavelli completed this work in 1513. It is a book consisting of 26 chapters, which contain the advice for the sovereign how to proceed and rule if he wants to achieve success and lasting fame for himself and for his country and pave the way for his followers. How to gain power and retain it instead of losing it? The individual chapters of The Prince are devoted to various forms of government, ways of acquiring and maintaining power, and the sovereign's qualities. Initially, the advice is not controversial, so it may seem to the reader that it is only a summary of dry recommendations. In the second part of the work, however, Machiavelli starts addressing topics such as virtue, fortune, and fate. Novelty and otherness of Machiavelli's ideas and opinions become the fundamental paradigm.

Advice formulated by Machiavelli caused a great response in Italy. In particular, this work presents and shows the reality realistically and with a light irony, as it is; it offers an undistorted view. Machiavelli presented his ideas clearly and directly. In an effort to bring the sovereign the best advice and thus ensure prosperity of his beloved Italy, he expressed his views frankly and in an unvarnished manner. He was not afraid to go against the tide, and he presented his truth, based on experience, without fear of consequences. Since the book was published at the time when virtually the only religion was Christianity, from which Machiavelli often grew apart, it is not surprising that due to controversial opinions and advice, the work provoked a great response. The 
author did not avoid councils that are criticized by various parties for their inhumanity and cruelty. If, however, they are the only way to achieve the goal, there is no choice but to apply them. Because of this idea, his name still evokes predominantly negative or even derogatory and offensive reactions. The question remains whether Machiavelli was indeed a supporter of cruelty and betrayal, or whether his main ideas were merely misunderstood. The Prince was primarily intended for Lorenzo de' Medici; Machiavelli wanted to give good advice to this sovereign on his way to become a great ruler. It was not just due to good intentions; Machiavelli also took care of his own interests, primarily of his return to political life.

\section{Egoism and Power}

Machiavelli based his recommendations on the assumption that the sovereign will rule over the people. He says that if he wants to govern well, to keep the power, to be respected, to be feared and loved at the same time, he must take into account the real human nature, what the people he will govern are like. Machiavelli sees human nature as treacherous and human beings as disloyal and dishonest. Human nature is actually hunger, desire, and passion after satisfying personal egoism, profit, wealth, and power. As long as people derive benefits from certain conduct, they are able to offer their blood and property, life and children to the ruler. However, therein lies their perfidy - they do so only when the need is very remote and there is no danger of its immediate fulfilment. If the need to help the sovereign in this way becomes imminent, it is entirely consistent with their nature that they begin to rebel. According to Machiavelli, these processes are typical and they are not bad in themselves; they only seem wrong compared to some of the ethical laws. Man is aware of how to live according to the moral principles so that his actions coincided with the Christian virtues. According to Machiavelli, however, the reality is often different, the society is corrupt, and to survive and be safe in such society, man acts contrary to morality. In order to keep the power, the sovereign must continue to think that human nature is primarily rottenness, people are naturally evil. Machiavelli said that if this principle was ignored by the ruler, he is pre-destined to failure and destruction (Q. Skinner and R. Price 1989, 74). Whenever one finds an opportunity, he will show his evil character, the bad side of his personality. Nevertheless, Machiavelli ignores human development. He perceives the world as unchanging and the same, with good and evil, which is moving from one country to another. Machiavelli shows that even historians urge rulers to consider the people bad and corrupt from the beginning, and as soon as opportunity presents itself to man, his bad qualities prevail. Badness can also be hidden, in which case time, which is the father of wisdom, will reveal it best.

In the Chapter 16 of The Prince, Machiavelli is concerned with the question whether it is better to be a feared, or a popular ruler. Both properties cannot reconcile. In this issue, the sovereign must proceed from the nature of the society. People are ungrateful, hypocritical, cowardly and greedy, and if the hand of the Lord is open, they would bend over backwards showing good will, they promise the moon. But when the crucial moment comes, they turn the tide. Lawmakers need to take into account that money is able to corrupt even very good people, so it is necessary to restrain the citizen's whims from the very beginning. Therefore, the sovereign has to choose respect instead of popularity, because he cannot rely on the society. However, being a respected ruler does not mean to raise fear that leads to hate, which results in upheavals, riots and turbulent times both for the society and the sovereign. Keeping respect means not touching the subjects' property and women. When it comes to the worst and it is necessary to shed blood, the ruler must have a good reason. The nature of man is to forget the human loss, but not the loss of property. The people are fickle and change their views; if the 
sovereign achieves glory, it does not mean that he retains it. It is therefore necessary for him to be constantly alert and ready to use force to push through his laws as soon as people lose faith in him. Therefore, it is necessary to consider this aspect of human nature and restrain the citizens' whims and ambitions. It is necessary that people counted on the fact that behaviour in violation of the law is followed by punishment. According to Machiavelli, the society does not like novelty and does not trust them. Therefore, those who advocate changes face a big barrier of resistance. However, once they overcome it, it may be easier for them to achieve fame than for anyone else, they gain power and prestige. Machiavelli says that the government can only be successful, if the ruler does not rely on his subjects' promises and trusts solely himself. People often pretend and conceal something; the ruler would be lost if he relied on their promises (N. H. Thompson 1992, 62). In order to be able to deal with the human nature of his subjects, he may not have all the qualities that are considered virtuous, but he must pretend that he has these characteristics, that it is his nature.

If, conversely, he has virtues, even in this case he cannot show them at all times and he has to stick to his role. Especially for the new ruler, it is undesirable to act only within his positive qualities. People are easily fooled by what they see at first glance. So when they evaluate the ruler's behaviour, they uncritically accept what is presented to them. In addition, they know the sovereign rather indirectly, the sovereign resorts to isolation and he is not in contact with the citizens, so it is not difficult to create an image of the ruler to the people's satisfaction. Finally, it should be noted that the sovereign is always judged by the outcome of his acts. If it is successful, the way it was achieved becomes unimportant. This is the idea for which Machiavelli is most criticized, and it shows why his name is often associated with falsehood and treachery (P. Strathem 2011, 32). According to Machiavelli, the main goal of the ruler is to maintain a functioning state. In order to achieve this, he often has to act contrary to his nature and resort to behaviour that is against all the God's and human commandments. A successful ruler must be strong and also act in contradiction with the concept of what is considered proper. If he wants to act virtuously in every case, among so many people who are bad and evil, he is necessarily doomed to failure. In extreme cases, if a political situation requires so, the ruler has to use violence, subterfuge, deceit, and murder if necessary to maintain the state. While the qualities that the people perceive as good can cause the sovereign, together with his government and citizens to fail, the qualities and actions that are considered bad, can, on the contrary, help him to achieve security and prosperity. When, however, a crisis situation is averted and there is no reason to continue the violence, it is necessary to go back to the previous method of government. Therefore, evil must be carried out quickly and efficiently, it must be in minority and it should be repeated the least frequently as possible. Then it will be accepted with divine and human support. The sovereign consistently has to show kindness so that the people were constantly aware that he acts for the public good (G. Craig and F. Gilbert 1986, 58).

\section{Techniques of Power and Virtue}

The concept of virtue-virtus derives from the Latin word for masculinity, prowess, grace, courage, and inner strength of personality. This term appears as early as in antiquity. For Christian philosophers, the term refers to the generosity and honesty of man; it is characterized by the fact that it generally covers positive character traits. The term is equivalent to the term areté. Machiavelli's term virtú is ambiguous (M. Ledeen 2000, 32); its meaning is not exactly defined anywhere. The basic virtues include wisdom, justice, courage, and temperance (let us also add magnanimity, generosity, honour, and glory). Only if the ruler acts ethically, he can achieve what he desires. Therefore, before The Prince was published, virtus had been associated with morality, 
and Machiavelli's contemporaries had kept repeating the arguments that are consistent with morality (Machiavelli 2004, 41). Machiavelli agrees with Christian humanists in many respects, as they see the right man in accordance with the best moral characteristics. Of course, it would be commendable if the ruler could act only according to his good qualities. He considers the belief that these virtues can be the means to achieve noble goals and great things as a mistake. The sovereign who would act this way would surely fail, which Machiavelli also verified in his previous experience in the political field and in the study of history. In contrast to the previous thinking, he realized that in order to achieve honour and glory, the ruler cannot always act in harmony with Christian virtues. He even sees a willingness to exercise power as a central element of good princely government. Machiavelli's conception of the virtue topic is important because it differs from the previous tradition and criticizes the religion of that time-Christianity. It raises the question of virtue warning that his analysis will differ radically from the existing humanist tradition. He preaches a return to the ancient world, he considers Christianity an error that untaught man traditional pagan virtues. A wise ruler must be able to separate personal virtues from public ones. If any private quality does not match the ones the proper sovereign should have, this personal weakness should be suppressed and avoided. It is not necessary that the ruler had all the qualities that are positive, but he should give the impression that he has them. However, if he has them, it is undesirable for him to act upon them all the time. Let him be benevolent, human, pious, honest, but all in good time. As soon as the need for the contrary arises, he must not hesitate. Especially, it is not possible to expect a new ruler to be all goodness. The circumstances literally force him to act against all God's and human commandments, bend to the wind when there is no other way and the interest of the crown requires so (Machiavelli 1855, 41). The Renaissance concept celebrates humble and timid men, while Machiavelli turns his back on this idea. Conversely, he gives precedence to energy, assertiveness, boldness, tenacity, courage, and determination over these virtues as qualities of a proper man, ruler, and warrior. Love of country is undoubtedly regarded as the greatest virtue. Machiavelli himself was a patriot and loved his country above all. His most revolutionary view was that cruel behaviour is also a virtue-in case it is applied as intended, at the beginning of the government, shortly and efficiently (D. Wootton 2008, 125).

\section{Conclusion}

The starting point of Machiavelli's political theory is the awareness of human ambivalence, which means that people are fickle by nature; when they let somebody convince them of something, this conviction does not last long. Statecraft does not develop in the world of perfect morality, but in the real world; this means that governance is mainly the knowledge and mastery of the forces that move the world. Statesman is one who can organize his own possibilities to handle these forces and use them for his goal. The state is merely a concentration of power. In terms of the purpose of government, only the result is good, justifying all the means employed, such as cunning, ruthlessness, and cruelty. In his conception, rulers do not hesitate, if necessary, to seize political power even by means of crime and apply the principle of divide and rule. In his book The Prince, he provided a detailed recipe for a method of government. Although this theory also provided the impetus for such movements as fascism, it still cannot be compared to the type of patronal government of Hegelian nature. Unlike Hegel, Machiavelli does not say anywhere that all means to preserve the state are necessarily good means. The purpose is not the destruction of the human psyche, but ensuring the benefit of the entire society. Machiavelli, however, completely overlooked the fact that the quality of any means used must comply with any purpose. Similarly, he was also unaware that the very fact of human imperfection also gives reason to mistrust 
the ability of the rulers themselves, and that therefore, the forms of government should be formed in the polemical action at the widest possible participation of citizens.

\section{Works Cited}

D., Wootton. Modern Political Thought: Readings from Machiavelli to Nietzsche. 2nd edition. Hackett Publishing Company, Inc., 2008.

G. Craig and F. Gilbert. Makers of Modern Strategy from Machiavelli to the Nuclear Age. 1st edition. Princeton University Press, 1986.

M. Ledeen. Machiavelli on Modern Leadership: Why Machiavelli's Iron Rules Are as Timely and Important Today as Five Centuries Ago. 1st edition. St. Martin's Griffin, 2000.

M. Unger. Machiavelli: A Biography. 1st edition. Simon \& Schuster, 2011.

N. Machiavelli. The Prince. University of Chicago Press, 1855.

---. The Prince and Other Writings (Barnes \& Noble Classics). Barnes \& Noble Classics, 2004.

N. H. Thompson. Machiavelli: The Prince. Dover Thrift Editions. Reprint edition. Dover Publications, 1992.

P. Strathem. The Artist, the Philosopher, and the Warrior: Da Vinci, Machiavelli, and Borgia and the World They Shaped. 60358th edition. Bantam, 2011.

Q, Skinner and R. Price. Machiavelli: The Prince (Cambridge Texts in the History of Political Thought). Cambridge University Press, 1989. 